\title{
Politics or profits along the "Silk Road": what drives Chinese farms in Tajikistan and helps them thrive?
}

\section{Irna Hofman}

To cite this article: Irna Hofman (2016) Politics or profits along the "Silk Road": what drives Chinese farms in Tajikistan and helps them thrive?, Eurasian Geography and Economics, 57:3, 457-481, DOI: $10.1080 / 15387216.2016 .1238313$

To link to this article: https://doi.org/10.1080/15387216.2016.1238313

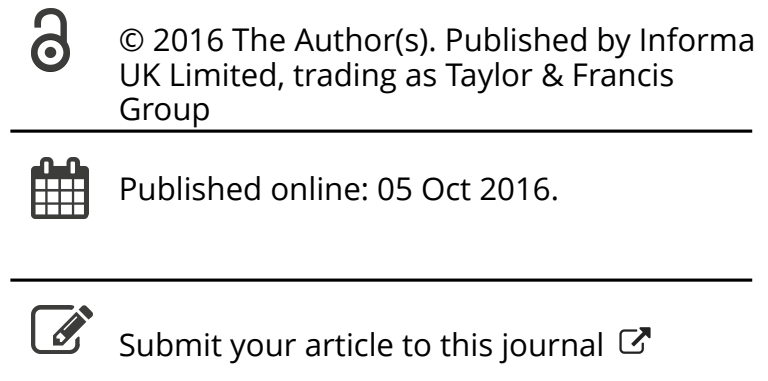

\section{Џ Article views: 2796}

View Crossmark data ¿

Citing articles: 8 View citing articles $\longleftarrow$ 


\title{
Politics or profits along the "Silk Road": what drives Chinese farms in Tajikistan and helps them thrive?
}

\author{
Irna Hofman \\ Leiden University Institute for Area Studies (LIAS), Leiden University, Leiden, The Netherlands
}

\begin{abstract}
China's influence in neighboring Central Asian states is growing at a fast pace. Since the launch of the One Belt, One Road (OBOR) initiative to accelerate China's engagement in Central Asia and beyond, nearly all Chinese activity in this region has been gathered under OBOR. OBOR now seems to cover a plethora of spatially and temporally expanding state and privately driven projects. In this paper, I discuss large- and small-scale Chinese farm enterprises in Tajikistan, in which discussions around China's "global land investments" and OBOR intersect. Beneath abstract conceptualizations of OBOR and the Chinese presence in Central Asia, my analysis shows that Chinese land investments in Tajikistan are shaped by Chinese dynamics of agrarian change and are contingent upon country-specific conditions. Rather than state-led endeavors as is often assumed, the main Chinese actors in Tajik agriculture are capitalist yet partially state-embedded enterprises driven by profit-oriented goals. Chinese farm enterprises tap into specific market demands that are either unanswered or underdeveloped in Tajikistan, or which have emerged due to the growing number of Chinese consumers in Tajikistan. The nature and drivers of Chinese land acquisitions in Tajikistan shed light on the various, sometimes competing, factors driving China's broader foreign "land rush," in Central Asia (and beyond).
\end{abstract}

\section{ARTICLE HISTORY}

Received 24 July 2015

Accepted 15 September 2016

\section{KEYWORDS}

China; Central Asia; Tajikistan; Silk Road; land investments; agriculture

\section{Introduction}

China's influence in neighboring Central Asian states is growing at a fast pace. One of the recent manifestations of this is Chinese land investment in Tajikistan. In 2011 popular media reported that 1,500 Chinese farmers would start agricultural production on 2,000 hectares in Tajikistan (Pannier 2011). In 2012 other sources reported that China would lease an area of 6,000 hectares (Vinson 2012). The news was soon reposted on an Internet "land grab" database (Farmlandgrab. org 2011) and thence portrayed in a way that fits within the general "land grab" 
discourse globally (cf. Grain 2008). The investment was thus typecast as part of the wave of Chinese global land investments that has been documented since 2008 (Grain 2008; Cotula et al. 2009; Bräutigam and Zhang 2013). While avoiding the term "land grab" because of its inaccurate connotations (as also argued by Hofman and Ho 2012; Bräutigam and Zhang 2013; Yan and Sautman 2010), this article aims to address a knowledge gap about China's engagement in agriculture in its neighboring region (cf. Visser and Spoor 2011; Henderson, Appelbaum, and Ho 2013). Moreover, by presenting a more comprehensive understanding of the ways in which China's "going out" takes shape in its direct vicinity, this article provides insights into the characteristics and implications of China's "going global."

Since autumn 2013, China's growing presence in Central Asia is placed within the Chinese government's Silk Road Economic Belt initiative as the land-based component within the popularized One Belt, One Road (OBOR, Yidai Yilu) (cf. Swaine 2014; Farchy 2016; Summers 2016). Therefore, the analysis of farmland investments in Tajikistan in this paper builds on and contributes to both analyses of OBOR and the Chinese presence in Central Asia (Laruelle and Peyrouse 2012; Summers 2016) and literature on foreign land investments (cf. Yan and Sautman 2010; Visser and Spoor 2011; Hofman and Ho 2012; Wolford et al. 2013; Gong and Le Billon 2014).

This paper is based on longitudinal field research focused on post-Soviet agrarian change in two villages in Tajikistan's southwestern Khatlon region and interviews with Chinese farm managers, Chinese farm workers, their Tajik assistants, and Tajik wage laborers conducted between March-August 2012, JuneSeptember 2013, and September 2014-February 2015. Field research insights have been supplemented with archive and media/web research conducted between 2012 and 2016. Based on my research on the nature of Chinese land investments in Tajikistan, I show that the contemporary processes of agrarian change in both Tajikistan and China are essential for understanding and explaining these land investments. The common assumption that it is the pursuit of security in food or energy that drives China's global search for land proves incorrect (cf. Grain 2008; for critique Yan and Sautman 2010; Hofman and Ho 2012; Bräutigam and Zhang 2013; Gong and Le Billon 2014). More in-depth critical research has also shown that other motives (also) drive Chinese land investments, which include among others, the export of technology, the search for market potential abroad (Yan and Sautman 2010; Bräutigam and Zhang 2013), and surplus rural labor ${ }^{1}$ (Bräutigam and Tang 2009, 694). In the context of Central Asia, one could raise questions whether border region stability and long-term geo-political/international cooperation play a role, as it is often assumed that Chinese growing presence in Central Asia and OBOR are mainly driven by geopolitical motives (cf. European Council 2015; see also, Cooley 2012; Laruelle and Peyrouse 2012; for a critique, see also, Summers 2016).

Examining various types of investments, I argue first that the large Chinese land investments and the specific orientation of the Chinese farm enterprises involved 
in the investments shed light on Tajikistan's political economy of post-socialist rural transformation. The Chinese companies tap into the emerging agro-industrial and food markets, where many Tajik farmers lack the political and financial capital to do so. Paradoxically then, the success of the Chinese farms may rest on the failure of Tajikistan's post-socialist transformation to develop a strong agricultural base and support the individual farm enterprise. Second, the Chinese small-scale farms' focus on satisfying Chinese consumers' demands in Tajikistan is an opportunistic response to the increasing number of (permanent and temporary) Chinese inhabitants in Tajikistan. These small farm enterprises thus engage in a new niche market, which emerged as an ancillary effect of the growing Chinese presence in the country. Hence, while both smaller and larger Chinese enterprises have a commercial orientation, their background and their market engagement differ strongly. I contend that these different kinds of Chinese farms in Tajikistan signify the major ways in which Chinese actors currently engage in agriculture on a global scale (see also, Yan and Sautman 2010; Cook et al. 2016); at the same time, they represent the diversity of Chinese actors involved in China's growing presence in the wider regional economy of Central Asia. Moreover, the types of Chinese farms in Tajikistan feature striking parallels with a typology of agricultural enterprises emerging in the contemporary process of agrarian change in China (Yan and Chen 2015; Zhang, Oya, and Ye 2015; Schneider 2016).

The next, second, section characterizes in brief China's contemporary dynamics of agrarian change and presents the specific context of Tajikistan's agrarian economy and China's contemporary presence in Tajikistan. This section also sheds light on the importance of state-society relations in understanding the actual materialization of investments on the ground. The third section is primarily based on field research in Tajikistan. It describes and analyzes different types of Chinese involvement in Tajik agriculture, including Chinese individual farms and larger investments, thus highlighting the various characteristics of these investments. The final section outlines this paper's conclusions.

\section{The push and pull factors of Chinese farmland investments in Tajikistan}

The variety of Chinese projects in Central Asia subsumed under the One Belt, One Road initiative is substantial, including infrastructure projects, investments, loans, and trade agreements by state, private and public-private enterprises. China's growing presence (and the specific impetus given by OBOR) understandably triggers major debates in terms of "who drives what, and why."Yet as Breslin $(2009,934)$ earlier noted, "We can ... argue about what drives what - whether international security concerns drive a change in economic strategy to mollify the region, or domestic political/economic perspectives drive a move to engage the region." Chinese authorities, international agencies, and media refer to OBOR, sometimes regardless of the exact starting points of individual projects or phenomena and regardless of the specific character of the Chinese presence, whether individual, 
corporate, or state-driven and whether focused on trade, finance, investments, or politics (cf. Swaine 2014; State Council 2015; Farchy 2016; Summers 2016). The initiatives clustered under One Belt, One Road go beyond investments for resource acquisitions and relate to domestic competition, regional stability, state finance, and labor issues. These aspects have also been noted in relation to China's "Western development" (xibu da kaifa) (Goodman 2004; Yeh 2009); the country's "going out" (zou chuqu), and Chinese global agricultural land investments (Yan and Sautman 2010; Hofman and Ho 2012). As Summers (2016) suggests, OBOR can be conceptualized as a continuation of earlier policies and goals rather than as an entirely new state-driven project, particularly as the often-mentioned drivers of China's global "going out" and Chinese global land investments have preceded and intertwine with OBOR.

At first glance, the Chinese investments in farmland in Tajikistan seem surprising. Tajikistan is not known as a country with highly productive farmland or with much potential for high-revenue agriculture. Only around $6 \%$ of the country's surface features arable land, and large parts of the rural population experience periods of food insecurity (World Bank 2016, 22). In addition, the costs of transporting perishable fruits and vegetables are substantial, and - with weakly developed transport corridors (cf. Peyrouse and Raballand 2015) - the bureaucracy and transaction costs are considerable for the export of goods in general. This suggests that Chinese land investments in this country have not been driven by the need to feed Chinese domestic consumers and hints at the need for a closer examination of locally specific characteristics and dynamics in agrarian development in Tajikistan, as well as in China, to understand these land investments.

\section{The role of Chinese agrarian dynamics in Chinese land investments in Tajikistan}

Understanding the plurality of Chinese actors involved in China's regional growing presence requires profound attention to developments in China's domestic economy. China's rural context is of great relevance to Chinese land investments abroad (see also, Schneider 2016). Contemporary dynamics of agrarian change in China echo characteristics of the country's economic reforms in earlier years in which the development toward a more market-based economy meant the privatization of Chinese state-owned enterprises (SOEs). It forced centrally planned enterprises - from national to regional and provincial levels - to dismantle and reconfigure themselves in a competitive market (cf. Yan and Sautman [2010, 315] on Chinese SOEs in Africa). This competition and enterprise differentiation also characterizes the process of agrarian transformation in China. The studies of Yan and Chen (2015) and Zhang, Oya, and Ye (2015) on the dynamics in Chinese agrarian society point to an accelerated capitalization of agriculture. In this process, the commodification of the means of production like the introduction of market-based mechanisms in accessing land have profound implications on social 
stratification in the countryside. For instance, the differentiation into distinct types of agricultural producers is characterized by large businesses taking the lead in modernization and smaller family farms facing subsumption into larger enterprises and incorporation into more complex and interdependent production relations. Going abroad can expand the market potential or can provide a resort to escape from domestic competition (see also, Yan and Sautman 2010; Schneider 2016). The going out of Chinese enterprises and individuals has unfolded into different migration patterns as well as into different trade and investment patterns overseas. China's state-owned companies have been assumed to head most Chinese overseas projects, particularly when it comes to their impact in economic, social, and geopolitical transformation (Hofman and Ho 2012; Henderson, Appelbaum, and Ho 2013, 1242). However, although individual and smaller scale activities are often little observed, Chinese individuals have, in fact, been the most active agents of entrepreneurship in China's growth abroad (cf. Gu 2009, on Chinese private companies in Africa).

From this perspective, OBOR as an initiative to accelerate Chinese expansion indeed embodies remedies to phenomena inherent to capitalism, like overcapacity and excess supply, as a spatial fix (cf. Harvey 2003), different from (only) geopolitical motives (as also argued by Summers [2016, 1]). Yet, while Summers (2016) asserts that OBOR is primarily a capitalist endeavor with geopolitical implications, in my view several goals are pursued in tandem, with commerce being undertaken by Chinese companies in conjunction with the Chinese authorities' efforts to gain presence and power. The facilities provided by bilateral agreements ease trade and investments. As Hofman and Ho $(2012,7)$ previously explained, the Chinese state plays a "vital role in planning and driving the off-shoring of production," which could be termed "developmental outsourcing."

Yet, whereas dynamics in China's economy are often attributed primary importance as factors engendering Chinese "going out" (cf. Summers 2016; Swaine 2014), the mode and orientation of Chinese actors overseas and the investments abroad are not less shaped by the conditions in host societies. It is rather the interplay of different foreign and domestic, and national as well as local, political economies that provide push and pull factors for investment and which shape the eventual realization of investments. Hence, here the context of Tajikistan is no less important in understanding the orientation of Chinese enterprises in this country.

\section{The Tajik context: post-Soviet agriculture}

With hardly any industry in the country, the agrarian economy is highly important in Tajikistan. As a whole, the agrarian sector contributes around $20 \%$ to the country's Gross Domestic Product (GDP) (Lerman and Sedik 2009; World Bank 2016). Yet there are severe impediments to rural and agrarian development. With the end of the Soviet Union, state support vanished, organizational structures broke down, 
and the supplies of agricultural inputs (such as agro-chemicals) gradually came to an end. Though the Tajik state began to restructure the former Soviet agrarian landscape through land and farm reform, it took a long time before the reorganization of the former collective (kolkhozes) and state (sovkhozes) farms truly took off (Robinson et al. 2008; Lerman and Sedik 2009; Hofman and Visser, forthcoming). The Tajik Civil War (1992-1997) left its imprint on society and on the rural sector, particularly in the southwestern Khatlon region.

Over $70 \%$ of the Tajik population resides in the countryside, and agriculture is the main source of employment for over $50 \%$ of the population (TajStat 2015b, 9; World Bank 2016). Access to land is important for the rural population, either in terms of a household plot or (employment at) a dehqon farm ("dehqon farm" is the general term used for private, individual and collective farms established on former collective or state farmland). Local differences in geography and off-farm employment options have resulted in varying degrees of competition over land, but also in differences related to farm size, crop mix, and farmer autonomy (Robinson et al. 2008; Hofman and Visser, forthcoming). The average size of a dehqon farm is around five hectares, but there are extreme differences - from isolated holdings of 0.5 hectares in the highlands to elite-run enterprises of a few hundred hectares or more in the lowlands (Hofman and Visser forthcoming). Notably, small-scale household plot production has continued to play a pivotal role for domestic food security and market supply (63.4\% of the total agricultural production volume came from household plots in 2014; TajStat 2015a, 27). The significant role of household plot production in market supplies of food crops is related to the fact that household plot production has been predominantly oriented toward horticulture crops, while most dehqon farms have focused on larger scale production of mainly wheat and cotton (Lerman and Sedik 2009; Rowe 2009; Hofman and Visser, forthcoming).

Yet, farming is insufficient as a single source of livelihood for most rural dwellers. Rural households are therefore forced to develop a highly diversified livelihood portfolio, which often comprises both on-and-off farm work, frequently including labor migration of one or more male family members. While the situation has improved, an environment conducive to individual farming has been missing for many years, and the absence of adequate infrastructure and underdeveloped markets still constrain agrarian development (see, for instance, USAID 2014).

The constraints in agrarian development and the lack of profits from farming are caused by a few interrelated factors. First, private sector development in the agro-industrial markets (of seeds and agro-chemicals) has been limited. This is related to the lack of perceived market potential among private enterprises and due to the absence of a (pre-existing) domestic agro-industry. As a result, farms face monopsonies of suppliers and high input prices. Second, innovations and scientific research in agriculture have been halted since the breakdown of the Soviet Union. As a result, knowledge and expertise, as well as education, have been shaped largely by Soviet agriculture that was oriented toward larger scale production practices (cf. Shtaltovna 2015; Van Assche 2016, 
385). As yet another legacy of collective farming, new individual farmers initially (and some still) often lacked an entrepreneurial mindset, as they were used to top-down decision-making in the planned economy. They often did not have the knowledge essential to run a farm enterprise or the experience to grow diverse crops beyond small-scale horticulture production on household plots. Many of the new farmers had become "farmers by default" (cf. Hierman and Nekbakhtshoev forthcoming) - that is, as former kolkhoz or sovkhoz shareholders after the breakup of the Soviet large-scale farms. A final, more pronounced factor that inhibits the development of agriculture is of a political economy nature. Although people can obtain land use certificates for inheritable rights over land by applying with the district authorities, the laws are ambiguous and are often shaped by patrimonial relationships and local power plays. As a result of continued elite and state interests in agricultural revenues (particularly from cotton, which makes up just below $15 \%$ of the country's export value; TajStat 2016), farm reorganization has been slow in the prime agricultural regions where elites have aimed to retain control over farms, which severely affects farmers' autonomy and ability to profit from farming (Robinson et al. 2008; Hofman and Visser, forthcoming). Despite the formal abolishment of the state's crop procurement system, elites' vested interests in mainly cotton have obstructed the diversification of production in lowland areas for many years and have stagnated rural and agrarian development. Moreover, in areas where the state has clearly withdrawn support, a lack of maintenance of infrastructure has resulted in deterioration of roads and irrigation and drainage systems, leading to severe soil salinization and desertification.

In a nutshell, Tajikistan's post-socialist rural transformation has resulted in a situation where most of the Tajik rural population are unable to live off their land, with institutions and infrastructure such as service organizations, financial institutions, markets, and rural infrastructure unable to support smaller scale farmers. Importantly, such an absence of access to markets and institutional support to smaller scale individual farming is a feature of the neighboring post-Soviet Central Asian countries too (cf. Spoor 2012; on Kazakhstan, see Toleubayev, Jansen, and van Huis 2010). Capitalization from below has barely been taking place in the Tajik countryside, and the few investments in farming are based on external capital (i.e. generated from off-farm work, migration, or industrial capital from by wealthier (local) actors). Initiatives and efforts to improve farm production and stimulate innovation in agriculture have until now been primarily donor-driven. Since the late 1990s, many international organizations and donors have initiated rural development projects such as the establishment of extension services, and set up grant schemes for machinery, agricultural technology, and farm inputs (USAID 2014; Shtaltovna 2015). However donor-driven projects have had to maneuver within the agrarian political economy, where particular crops and practices are prioritized over others, and where access to land, farmers' autonomy, and the ability to farm depend on (local) political patronage (Hofman and Visser, forthcoming). 


\section{China as a benefactor to the Tajik economy?}

Against the background of an impoverished rural sector and a capital-short state, the Tajik government announced Chinese land investments in 2011 as beneficial to Tajik agriculture. The particular Chinese investment that was announced in 2011 was said to lead to an upgrading of production, an improvement of farming conditions, and it would create rural employment.

Tajikistan ranked poorest in Soviet Central Asia, and as noted, the breakdown of the Soviet Union and Tajikistan's Civil War have had worse impact on Tajik society and the economy. The economy started to recover in the late 1990s (with a positive GDP growth rate since 1997; see also, Figure 1). The relative importance of different sectors for the national economy has remained fairly stable over the past few years. The importance of the agrarian sector for the national economy has gradually declined - from 35\% in 2000 to 20\% in 2015 (World Bank 2016). A small number of commodity exports has been critical for the economy (aluminum, cotton, and labor [migration]), which makes the economy highly vulnerable to external shocks. Migration to Russia has started to take off since the aftermath of the Tajik Civil War, in parallel to what has been seen in neighboring Central Asian countries since their independence, where post-socialist transformation has pushed people off the land and where the national economy has lacked sufficient employment opportunities. Money transfers by labor migrants have been critical for individual households and the Tajik economy in general (as the trend in Figure 1 also clearly indicates). Tajikistan stood out in Central Asia in relative terms of the importance of migration for the domestic economy in the past few years, and even also worldwide: Tajikistan has ranked highest in terms of the contribution of migrant transfers to the national economy, as in 2013 remittances equaled more than $50 \%$ of the GDP. Both the decline in GDP and in migrant transfers from Russia after 2013 have been due to spillover effects of the economic downturn in Russia (World Bank 2016), whereas the restrictions set by the Russian government on labor migrants from Central Asia and the growing hostility toward Central Asian

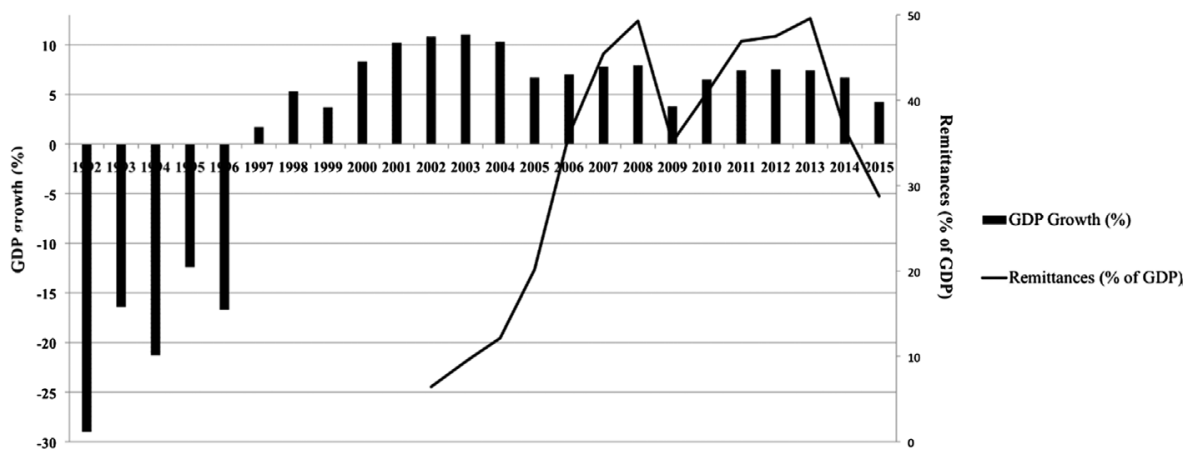

Figure 1. Tajikistan's Gross Domestic Product growth rates and relative importance of remittances (1991-2015). Source: Author's drawing based on World Bank data 1991-2015 (World Bank [various years]). 
migrants among the Russian population have also played a role in the decrease in labor migration. Yet, still in 2015 around one million Tajik migrants (10-15\% of the total population) reportedly migrated (World Bank 2015).

Against the background of the contraction of the Russian economy, the importance of Chinese capital for Central Asian economies has grown rapidly. Central Asia emerged as a frontier zone for the Chinese economy in the years after the dissolution of the Soviet Union, and the region's importance for the Chinese economy has been growing ever since (Kassenova 2009; Laruelle and Peyrouse 2012; Cooley 2012; Laruelle 2015; see also, Breslin 2009; Kerr 2010). Chinese land investments thus clearly fit within the larger trends with regard to China's growing role in Central Asian states' economic development and the shifting geopolitical relations in the region. China has become a prime economic partner in terms of state credits, loans, and investments. The Tajik establishment has turned toward China, rather than Iran, Russia, or Europe (as asserted by a Tajik senior scholar at the Academy of Sciences, interview 17 February 2015). According to the director of the Center for Strategic Research under the President of Tajikistan (interview 18 February 2015), China is seen as the generous non-conditional creditor that offers a welcome alternative to the more "traditional" donors, in fact as a "lender of last resort"2 (Sattori 2013). In 2013, Chinese Foreign Direct Investment (FDI) accounted for almost 50\% of all FDI in the Tajik economy (Ministry of Foreign Affairs 2014), and the importance of Chinese investments has further increased: the Chinese government pledged investments totaling two billion USD in 2014; for the 2015-2018 period, the Tajik government announced a new Chinese governmental investment package totaling six billion USD (Farchy 2014).

\section{The role of host countries' state-society relations and perceptions of "China"}

Whereas Chinese investments have been taking place all over Central Asia, especially in infrastructure and mining, Chinese investments in farmland have only materialized in Tajikistan. As is the case throughout the Central Asian states that feature pronounced regional and land-based identities and where postSoviet nation building has meant a resurrection of national borders (Collins 2006; Hierman and Nekbakhtshoev 2014; Reeves 2014), the Chinese land investments triggered anxiety in Tajikistan. Despite the hostility, the land acquisition did take place. In interviews with villagers (April and May 2012), people recited newspaper headlines like Tajiks to Russia, Chinese to Tajikistan? (Faromarzi 2012). Yet outspoken expressions of resentment have remained absent. This absence is due to the country's strengthening authoritarian regime, in a context where the civil society has already been severely circumscribed (see also, Heathershaw 2009). The legacy of the Tajik Civil War also plays a role here, as many people fear recurring violent conflicts. 
State-society relations in the host country and the host populations' perceptions about "China" can (drastically) alter the actual crystallization of investments. The way in which investments materialize is contingent on local socio-political dynamics and characteristics. Although the neighboring Central Asian states feature constraints in agrarian development similar to Tajikistan (as mentioned above) that may trigger foreign investment in agriculture, in Kyrgyzstan (2004) and in Kazakhstan (2009 and 2011), previously announced and planned investments in farmland were canceled after large protests (Centrasia 2004; Demytrie 2010; Visser and Spoor 2011). ${ }^{3}$ In April 2016, again various large protests took place in Kazakhstan against a planned amendment of the Land Code that would enable foreigners to lease farmland for a longer term (up to 25 years). In response to the protests, the Kazakh government placed a one-year moratorium on the Land Code, which halted the planned amendments (Orazgaliyeva 2016; Putz 2016).

The Tajik population's anxiety regarding China's growing presence reached a climax in 2011 when a longstanding border dispute between China and Tajikistan, originating in the late 1800s, was finally settled (Bitabarova 2016, 67, Alimov 2012). As Olimova $(2008,64)$ describes,

China claimed three disputed sites in the territory of the Gorno-Badakhshan Autonomous Region ... totaling to an area of over 20,000 square kilometers. In 2001, after a long period of coordination, Tajikistan agreed to transfer more than 1,000 square kilometers of this territory to China.

By 2013, the border had shifted. While there were no settlements in the disputed area, Tajik herders lost their pastures (Bitabarova 2016). The fact that the ratification was concluded almost simultaneously with the publicized large-scale Chinese farmland investment, discussed below, augmented the population's fear. Public information about the ratification of the agreement was scarce, and many Tajik people feared that their government would cede more land to the Chinese government in the future. In turn, these fears added to speculations about China's growing presence in the country. There are no reliable statistics with regard to the number of Chinese migrants, but analysts and media have reported numbers ranging from 15,000 up to even 80,000 (Judah 2011) if informal and temporary migration were to be included. Details of specific contracts and investments are scant, and as a result, wariness regarding Chinese "takeovers," colonization, and Sinification has frequently circulated in (despite rather state-controlled) media (see, for instance, Muhammadiqboli 2009; Nasriev 2011; Faromarzi 2012; Ganjinai 2012; Tursunzoda 2013; on similar observations in Kazakhstan, see Sadovskaya 2007; Burkhanov and Chen 2016).

However compared to the initial, rather monolithic negative discourse on China, Tajik people's perceptions of the Chinese presence and China itself have begun to differ across social strata. This has resulted from more personalized encounters between Tajik and Chinese individuals and the more pluralistic forms of Chinese engagement in the Tajik economy. Whereas the Tajik regime supports Chinese 
investments and seeks to legitimize Chinese companies' operations as benefactors to the economy, the Tajik intelligentsia, which mostly distances itself from the post-Soviet regime, remains skeptical. For middle and lower classes, Chinese investment and the presence of Chinese companies may mean business and employment, including in the agrarian sector. A change in perceptions of China particularly occurs through personalized encounters on the work floor or in business, where the grander "China" is being unpacked and challenged (bearing a resemblance to Dyatlov's [2012] observations of similar discourse shifts in the Russian Far East). For many young adults, the Chinese economy (including Chinese investments in Tajikistan and businesses in China) now offers a potential future. Saliently, I observed (in the winter of 2014-2015), that several Chinese companies are replacing their Russian-speaking Chinese staff members with Chinesespeaking Tajik assistants. The learning of Chinese can be interpreted as a pragmatic decision of Tajik parents to secure future employment for their children or the product of a longer term vision of the Chinese government to lay the foundation for infrastructure in both physical (i.e. roads, transit corridors) and human capital terms. Thus, although some still outright fear a Chinese takeover, more nuanced notions have also developed over the last couple of years. These shifts are important for understanding the way in which the Chinese presence has been unfolding on the ground.

\section{Different forms of Chinese agricultural engagements in Tajikistan}

In 2011, international media articles reported a case of Chinese land investment in Tajikistan where 1,500 Chinese farmers were to start cultivating 2,000 hectares of farmland in Tajikistan's primary agricultural region, Khatlon (Pannier 2011). In Tajik and Chinese media, it was said that the investments would yield better crop production, improve field conditions, and upgrade agricultural knowledge and technology (Asia Plus 2014; Nosirjon 2014; Xinhua 2014a, 2014b). Demonstration plots would be set up, and Tajik farmers would benefit from knowledge transfer (Nosirjon 2014). According to Chinese media, five demonstration areas were assigned (China State Farms 2014). Tajik governmental officials were cited in local media:

We will consider the widening of farming land for this company to include lands that are not in proper use by other farmer communities, and we expect further collaboration between the company and farmer communities in Yovon, and the import of new and more fertile seeds of wheat from the farmers of the Henan district. (Nosirjon 2014)

However, during an exploratory trip through the Khatlon region in 2012, I had difficulties locating any Chinese farmers. The authorities remained vague regarding the exact locations of the Chinese land investments. Tajik rural dwellers, authorities, and foreign expats with whom I spoke were little informed about the actual developments and conflated a variety of different Chinese farms and projects in agriculture into one large investment. 


\section{Tapping into the Tajik market: large-scale Chinese land investment in Tajikistan}

The Chinese land acquisition that was announced in Tajikistan in 2011 referred to a Chinese company that started its operation in Tajikistan in 2012. Since the company's Chinese and Tajik names differed, and due to the secrecy around the company's operations, understanding the background of this supposedly "single" investment appeared a complex issue. In fact, different operations have been covered under one umbrella corporation, named Jing Yin Yin Hai (in Tajik, Szinnyan Inhai LLC). Since its start, the Jing Yin Yin Hai company has grown, and by 2015 its operations had vertically integrated. The company's headquarters are set in Dushanbe, and it has been operating in different districts; namely Yovon (cultivating cotton, staples, and vegetables), Jaloliddini Balkhi (the company left this district after 2013, but cultivated rice, corn, and cotton), and Vahdat (seed factory). Up to 2013 the total operations covered around 415 hectares; in January 2015 the area under cultivation was over 500 hectares, with plans for further expansion in the next few years. Local media reported figures as high as 6,300 hectares (Chorshanbiyev 2015), but whether the investment really unfolds accordingly, remains to be seen. The company's actual operations are up until 2015 significantly smaller than reported in the earlier media articles (Pannier 2011; Vinson 2012). At the same time, they differ from the initial statements of Tajik governmental officials, since the promise of establishing extension activities for Tajik farmers has not been fulfilled.

Jing Yin Yin Hai's establishment in Tajikistan was initiated by a former official of the Chinese Ministry of Agriculture, who had observed the profit potential of investment in the Tajik agricultural economy. Initially involved only in the crop seed business, the former official attracted other Chinese companies to expand business in Tajikistan. As of 2015, there were two principal companies involved in this co-venture ${ }^{5}$ : Huang Fan and Jing Yin Yin Hai Seeds, both from the Henan province. The operations of Huang Fan and Jing Yin Yin Hai Seeds differ in crops and approach, as do their origins. Their goal, however, is aligned in that they both aim at the development of markets in agricultural crops (including fresh vegetables and staples like wheat and cotton), and perhaps with more long-term importance, the development of the agro-food industry (in crop seeds and technology). Jing Yin Yin Hai's operations point at attempts to gain control over production chains, as opposed to only controlling land as a means of production.

The farm enterprise Huang Fan, as one of the two companies involved in Jing Yin Yin Hai, has been concentrating on the large-scale production of wheat and cotton in Tajikistan. It has a license to sell, breed, and cultivate home-grown (Chinese) wheat and a cotton seed variety (called "Inshan-2") and to export cotton lint (Asadov 2013, 19). Founded in 1951, Huang Fan has a long history. As a result of increasing production costs and land rental prices in China, the company's profit margins have decreased. At the same time, the increase in mechanization of farming in China resulted in worker surplus, and these factors together have driven the 
company to search for opportunities abroad. Prior to investing in Tajikistan, the farm's leadership also investigated the situation in Vietnam, Laos, and Cambodia. In the end, it decided to invest in Tajikistan and Ukraine, where it assumed it would find good production conditions and policy benefits (Xinhua 2014b). Tajik district authorities have been playing an important role in the Chinese company's land acquisitions, as they are the principal governmental body responsible for issuing land use certificates. Also in other matters, the Chinese company clearly benefits from connections with Tajik authorities, who, for instance, facilitate the further spread of marketing potential locally and to other districts in the country. The company has its own cotton gin and has set up contract farming schemes with local Tajik farmers, in which it provides credit and farm inputs. The target for 2015 was to contract cotton-growing farmers totaling an area of 3,000 hectares (as stated in an interview with the head of the local government [jamoat],18 December 2014). Huang Fan's operation through contract farming schemes allows the company to expand, control, and discipline production. For Tajik authorities and elites with stakes in the cotton value chain, the company's operation may be regarded as a safeguard to uphold cotton production. According to the Chinese staff, the company has been asked to cultivate cotton on (at least) $60 \%$ of their fields (interview with the company's financial manager, 5 January 2015). This percentage is comparable to what is still often enforced upon Tajik farmers, which is to cultivate $50-70 \%$ of their fields with cotton). Since cotton in Tajikistan is highly important for the economy as a critical foreign exchange crop, as noted, engaging in the cotton value chain has considerable potential for profits. At the same time, it is risky to engage in this elite-controlled economy.

A striking issue here is that Huang Fan has actually replaced a Swiss agribusiness that operated in the same area and that also procured cotton through contract farming schemes, and owned a local ginnery. While one reason for the Swiss company's exit may have been financial difficulties, it has been said (in informal conversations with European expats) that it was compelled to leave primarily because it had been perceived as a threat to the local elites' cotton businesses. The role of elites in this Chinese investment is also substantiated by a related case of competition among Chinese companies. Before Jing Yin Yin Hai settled in the Yovon district in 2013, a Chinese family farm had been working for one year on the same the fields - ones which belonged to a large Tajik landowner living in a northern district. When Jing Yin Yin Hai arrived, the Chinese family farm was compelled to move to a district north of Dushanbe, where it was given fields by the same Tajik landowner.

Another salient case that sheds light on the role of the local agrarian political economy in Chinese land acquisitions is an instance where Jing Yin Yin Hai was given "abandoned land" in the southern Jaloliddini Balkhi district. In this district, the rural infrastructure had become dilapidated after the Tajik Civil War of the 1990s; the worsened production conditions have also been caused by the continuing monoculture cropping of cotton. District authorities legitimized the 
Chinese investment by stating that Jing Yin Yin Hai would rejuvenate the fields and infrastructure, for which both the cash-strapped state and local farmers lacked resources. Yet, the abandonment of land here was not caused by a lack of farmers' entrepreneurial attitudes or inefficient practices, but had deeper political economy origins. Local elites in this area have used their administrative rights and power to divide farm assets and liabilities in the process of farm reorganization, of which cotton debt has been an essential component. Many local farmers have become trapped in debt-bondage, and debts have come to serve as a coercive mechanism to produce cotton. In turn, cotton debts have become a major impediment to the development of local farms and have led to land abandonment. The Chinese company was given "abandoned" fields by district authorities without any debt, and without further production requirements. This created discontent among the local inhabitants. Although the Chinese investment did not dispossess the villagers in question, the company could benefit from pre-existing inequalities when acquiring access to land. However, even though the Chinese company attempted to rehabilitate the irrigation and drainage systems, it could not achieve adequate harvests; thus, it left this location after the production failed for two consecutive years (cf. Ergasheva 2014). The failure to realize profitable harvests was decisive for the enterprise to leave.

This latter example clearly demonstrates the role of the agrarian political economy in Chinese land investments and how local patron-client relationships indirectly enabled the investor to access land. As Wolford et al. (2013) argue, the role of the state and the local political economy are critical in shaping and facilitating foreign land acquisitions.

Complementing Huang Fan's cultivation of cotton and staples is Jing Yin Yin Hai Seeds'focus on vegetable seed and crop production. The company was founded in China in 2007 and was granted the status of a leading enterprise in seed technology by the Henan province in 2011 (Jing Yin Yin Hai, n.d.). In Tajikistan, the company had expanded operations and (as of 2015) includes a vegetable-producing unit (October 2012); a seed-processing unit (registered in July 2013); and a flour-processing factory (July 2013) (as stated on the Chinese website Zhiqiye; Guangzhou Yuandao 2015). The expansion of the company's operations has become visible at the field site and in the central bazaar of the Tajik capital, where the company's managers and translators negotiate for good prices of fresh produce with middlemen on a daily basis. Besides this outlet, Chinese private businessmen have engaged in vegetable purchases for a part of the company's produce directly at the farm gate. The focus is on the production of vegetables, crop seed, and the development of agricultural technology, particularly greenhouses, all of which have a great potential given the lack of competition from both rural households' plot production and dehqon farms. This leaves ample market potential for the Chinese company. Jing Yin Yin Hai Seeds' produce comprises both vegetables used in Tajik cuisine such as onions, tomatoes, cucumbers, and chili peppers, and particular Chinese vegetables such as beans, melons, eggplants, and cabbage, which 
are produced in smaller amounts. The company introduces new varieties in local markets and in doing so, enhances the availability and diversity of vegetables, particularly in the winter season, since crops are produced in greenhouses. This development thus challenges initial assumptions that Chinese "land grabs" are driven by Chinese domestic food demands. By introducing new seed varieties, crops, new technology, and a market of agro-chemicals, the company strives to gain control over particular agricultural value chains, both upstream and downstream. In an interview (6 January 2015), the Chinese farm managers explicitly stated that they aim to become the largest vegetable-producing enterprise of Central Asia, with outlets to Russia, Afghanistan, and further abroad. The company may regard its investment in Tajikistan as a way to enter the Central Asian agricultural market, where, (as explained above, in Kyrgyzstan and Kazakhstan) similar profit potentials may be found, but where access to agricultural land has proven to be more contested.

While Chinese managers and specialists run Jing Yin Yin Hai, the work in the fields and in the greenhouses rely on locally hired labor. Local authorities initially had an important role in recruiting Tajik villagers, but in later years the organization of labor has been facilitated by the permanent appointment of villagers as guards and field supervisors. For landless villagers, the salary offered by the Chinese has been relatively higher than what they would earn by working for local farmers, although the work is more demanding (as local workers and villagers mentioned in different interviews in July-September 2013 and December 2014-January 2015). Wage labor at the Chinese company has especially become more attractive for local male Tajiks, since conditions of labor migration to Russia have worsened.

A second large-scale land acquisition by a Chinese investor, reported on Chinese television (Henan TV 2012), is another example of how China's dynamics of agrarian change and both Chinese and Tajik political economies of land play a role in Chinese land investments in Tajikistan. While I have been unable to locate this farm during fieldwork, according to the interview on Henan News, it would comprise around 800 hectares (12,000 Chinese $\mathrm{mu}$ ), based on a leasehold arrangement for a period of 49 years (Henan TV 2012). The investment was pledged by a Chinese agricultural entrepreneur from the Henan province, who started a "cooperative" in China in 2007 while learning to use modern agricultural technology. ${ }^{6}$ On Henan News (Henan TV 2012), he talked about his experiences in Tajikistan in later years:

"I was thinking about finding opportunities to make profit for my cooperative. The idea of going abroad to make profit came to my mind." Mr. Han consulted a friend who had gained experience abroad. "In August of last year, a friend of mine told me that the countries near Russia have vast barren lands, as people there are mostly herdsmen instead of farmers. We first went there to investigate ... In our country (China), the land-leasing fee is 1,000 RMB per mu, while in Tajikistan, the corresponding price is 13.7 RMB per mu. Taking other fees into account, the price per month is between 500 to 600 RMB."... Henan News continues: "Mr. Han has established an efficient and high-level agricultural zone in Tajikistan." Mr. Han laughs, "We feel proud of ourselves. I have never imagined that I could become well-known by farming." 
These examples of Jing Yin Yin Hai and Mr. Han's cooperative demonstrate that the Chinese domestic context and the goal of capital accumulation clearly drive investments, while host country conditions further shape the enterprises' orientation. Although the company Jing Yin Yin Hai and "cooperative" discussed here have different management and ownership structures, they also have important features in common. Both are regarded as vehicles of agricultural modernization in contemporary China. As Yan and Chen (2015) describe, an accelerated capitalist development in the Chinese countryside is leading to a highly stratified rural society, where dragon-head enterprises are expected to spur agricultural modernization. Interestingly, Jing Yin Yin Hai takes up such a role in Tajikistan, and has a clear longer term orientation to expand and diversify the business. The cooperative of Mr. Han could be regarded as an example of the growing prominence of commercial capital in China's agrarian development, where access to farmland is increasingly organized through market mechanisms. This may incite agricultural entrepreneurs like Mr. Han to start companies abroad. Both investments were triggered by the assumed profit potential of investment in Tajikistan's agrarian economy. The enterprises are able to profit from the fact that agrarian development has been stagnant in the country, and can benefit from the pre-existing inequalities in access to the means and factors of production: land, agricultural technology, farm inputs, and control over agricultural value chains.

\section{Small-scale Chinese farms in Tajikistan: satisfying Chinese consumers' preferences in Tajikistan}

Whereas large-scale Chinese projects and initiatives tend to dominate the Tajik media, less analyzed are Chinese individuals' enterprises and cross-border trade. Many Chinese individuals have crossed the border in the last few years, after having learned of the lucrative nature of doing business in the frontier zone of Central Asia. ${ }^{7}$ Individually initiated Chinese farms in Tajikistan are exemplary for this kind of entrepreneurship. In this section, I highlight two kinds of farm enterprises, different from the ones portrayed above in that their markets and outlets are more narrow and specific. While varying in land tenure, focus, and size (yet primarily within a range of one-half to five hectares), the origins of these two types of small farms are directly related to the growing presence of Chinese actors in Tajikistan.

The first type of small-scale Chinese farms is one run by Chinese individuals, who grow vegetables for private consumption or to supplement their income from formal employment at Chinese companies. These small Chinese farming endeavors are self-organized. The migrants lease land for only one or a few growing seasons in the direct vicinity of their accommodation. In most instances, they work individually or they cooperate within their network of friends or colleagues. The people undertaking these activities sometimes have a rural background, but not always. The demographic structure of the Chinese society plays a role here: most Chinese people who currently work in the urban (i.e. industrial) sectors have a rural 
background and are used to cultivating their household plots intensively. While they changed their occupation by migrating, they use their farming experience to supplement their wage income once abroad or to satisfy their specific food preferences. In the Yovon district, for instance, two Chinese men working at the Chinese cement factory in the district center leased a field of a few hectares from a local farmer in 2012, for only one year, where they grew potatoes and onions. This kind of land tenure is very different from the longer term leasehold arrangements described above, where contracts are signed with district authorities for a longer period of time, most often for 49 years. Local Tajik inhabitants assumed that the field cultivated by the two Chinese men was part of the larger Chinese land investment by Jing Yin Yin Hai described above, and though the farm activities were in the same locality (jamoat), there was in fact no connection between the two.

Another type of Chinese small-scale farming that targets the Chinese consumer market in Tajikistan is of a more established, permanent, and commercial kind. It differs from the former one in that its primary goal is capital accumulation rather than a non-remunerating side activity. One example is a Chinese family who originated from the eastern part of China. They moved initially to the capital of the Xinjiang region, Urumqi, and decided to cross the border and settle in the Tajik capital in 2009, where they expected to find better income opportunities. The family managed to rent a shop in the central bazaar in the Tajik capital to sell dry goods imported from China. They soon observed a demand for particular Chinese vegetables and were able to lease a small plot (around one hectare) from a Tajik woman near their house.

The revenues from the fields and the shop provided the family with a good but not extraordinarily high income. The family rehabilitated old greenhouses that had been left on the fields, which allowed them to cultivate vegetables throughout the year, such as cabbage, spinach, and beans. All inputs required for the production were imported from China. Besides vegetables and dried products, the family also has been selling pork ordered from Tajik suppliers. The shop was not their only outlet. More commercially significant outlets were Chinese restaurants and Chinese companies that run their own canteens. The family clearly responded to a niche they observed - supplying Chinese individuals and companies. They started as petty commodity traders but branched out to become commodity producers. The enterprise's potential to develop seemed significant given the fact that it served an expanding Chinese community and was located close to a neighborhood that seemed to become the Chinatown of Tajikistan's capital (as observed in winter 2014-2015 and April 2016). The enterprise clearly engaged in a market niche that has emerged and grown in the past few years. The value chain of the farm's produce was short, but the highly specific market segment implied guaranteed sales, and there had not been much market competition for the specific produce at the time of the interviews (January 2015; for personal reasons this family had to leave in summer 2015, but their business was taken over by other Chinese). 


\section{State support}

It seems logical that the various Chinese farm enterprises would benefit from the agricultural cooperation agreement between China and Tajikistan (Yuldoshev 2014; see also Zhang 2015), certainly now that great impetus is given to China's regional expansion in Central Asia and beyond. There are clear incentives provided by Chinese authorities to agricultural companies to look across the border; a notable one, for instance, being the information they provide about investment opportunities in Tajikistan (Bureau of Foreign Affairs 2015). However, I have not been able to substantiate evidence of state support in interviews. The Chinese companies appeared to be entirely responsible themselves for competing with Tajik traders for market outlets in nearby urban areas. There were no indications of a strong connection with the Chinese central government, either technically or politically, while Tajik authorities appeared to have a clear role in mediating access to land.

At the same time, Jing Yin Yin Hai's expansion seems typical for the developmental trajectory of dragon-head enterprises, in which the Chinese state has an important role (Schneider 2016). "Dragon heads represent a kind of state-private nexus that challenges strict state/private binaries" $(2016,10)$. Jing Yin Yin Hai is the first agricultural company from Henan that has executed the province's "Going Out" strategy, as Chinese media and the company website affirmed (Xinhua, 2014a; Jing Yin Yin Hai, n.d.). The company thus clearly follows up on governmental aspirations, which fit the policy of "developmental outsourcing" (Hofman and Ho 2012). As the Chinese ambassador in Tajikistan stated on the website of his embassy (May 2014): "Today, the Chinese people will sow the seeds of friendship in the Tajik land, tomorrow it will reap rich fruit of bilateral pragmatic cooperation" (Embassy 2015). This apparent role of Chinese authorities, and in particular the role of the regional authorities of the Henan province, supports Summers (2016) argument that OBOR includes policy incentives separately undertaken by the Chinese regional authorities. Thus, the Chinese state plays a role in facilitating Chinese private investment. The ways in which consequently Chinese companies develop, may highly differ.

\section{Conclusions}

In this paper, I aimed to highlight the variety of Chinese actors involved in the Tajik economy, with a particular reference to land, and the factors that drive these actors to invest in Tajikistan. Nearly all contemporary Chinese presence in Central Asia is analyzed from a macro perspective and subsumed under the development of the One Belt, One Road initiative. The considerable attention given to OBOR by the media and in the international (political) arena suggests that China's presence in Central Asia and beyond is all part of a grand plan of the Chinese government. The focus on such grand narratives and the rhetoric about "land grabbing" make invisible the actual complexity and heterogeneity of Chinese land investments on the ground. The variety in Chinese farm enterprises I observed, which may 
continue to grow and change, indicates that only detailed analyses can properly detangle the actors involved and their motivations. By contrasting two types of Chinese farm enterprises in Tajikistan, I have sought to elucidate the dichotomy between Chinese farm enterprises as well as their drivers, the ways in which they interact with the Tajik society, and the different segments of the consumer and agricultural markets.

First and foremost, I have demonstrated that commercial motives drive Chinese farm enterprises in Tajikistan, rather than geopolitical imperatives. Beneath this notion of "commerce," my in-depth analysis has shown that commercial interests manifest in distinct ways. The Chinese actors in Tajikistan's agriculture are profit-oriented, but the manner through which they access the means and factors of production differ, as does the way in which they capitalize on their produce and business.

Large Chinese enterprises clearly tap into segments of the domestic market that have been underdeveloped in the process of Tajikistan's post-socialist agrarian change, with factors related to the political economy and Tajikistan's Soviet and civil war legacy. With its production of crops and specific focus on seed breeding, the company Jing Yin Yin Hai aims to engage in and profit from upstream and downstream markets, including the attempt to export technology. While the production is currently destined for the Tajik market, the company may expand sales across the Central Asian region in future years to neighboring republics where a similar profit potential in the agrarian economy may exist. As such, Jing Yin Yin Hai's profile has similarities with an "agro-capitalist" Chinese farm in Zambia (Bräutigam and Tang 2009; Yan and Sautman 2010). This agro-capitalist tendency contradicts the common narrative on Chinese agricultural ventures abroad. The smaller Chinese farms are also commercially oriented, but focus on a market niche which is much narrower and very specific, triggered by the growing Chinese consumer demand in Tajikistan.

Second, as noted before, the Chinese context plays a major role in these foreign land investments. The typology of Chinese enterprises in Tajikistan presented above seems to be a testimony to the main actors in Chinese agriculture - family farms, cooperatives, and dragon-head enterprises (Yan and Chen 2015; Zhang, Oya, and Ye 2015). This typology reflects outcomes of contemporary rural differentiation processes in China, where going abroad may offer options for Chinese companies to expand or yet prevent a forced exit from the agricultural sector. The specific case of the Chinese family described also more generally represents Chinese individuals' choice to come to Tajikistan - an opportunistic decision in search of a better livelihood. The lack of employment opportunities, competition on the domestic market, meager retirement payments, and stringent labor regulations are driving part of the migratory processes.

To conclude, a joint analysis of Tajikistan's post-socialist agrarian transformation and Chinese dynamics of agrarian change is essential to understanding the origins of these investments and the ways in which they materialize (or not). Answering the 
question of "what drives the Chinese farms in Tajikistan and helps them thrive" thus requires looking beyond grand narratives. Understanding China's role in and drivers of overseas farming warrants zooming in on context-specific characteristics within and beyond borders. Only through such an exercise can the complex amalgams of Chinese actors be unpacked and abstract conceptualizations be challenged.

\section{Notes}

1. Some have argued that agricultural investments function as a way to channel labor surplus from China's poor rural areas abroad. Bräutigam and Tang $(2009,694)$, for example, found that (in the late 2000s) "Chinese observers began to comment that agricultural investment in Africa also had the potential to relocate Chinese farmers displaced through the dual pressures of WTO trade liberalization and China's rapid urbanization."

2. However, Chinese involvement in peacekeeping missions (for instance, in Mali in 2015) points at a change in foreign policy, like Alden and Large (2015) have also noted in relation to China's foreign policy regarding African states - from a non-conditional creditor to an actor that starts to engage in "norms making."

3. Rumors of Chinese colonization and large Chinese leaseholds circulated in the Kyrgyz media, although they were never confirmed (Centrasia 2004). The framing of the supposed deal hinted at discrediting the president of that time. In Kazakhstan, "local authorities of the autonomous Kazakh region of Ili in Xinjiang" acquired rights to lease 7,000 hectares, but whether or not this leasehold agreement materialized has never been clarified (Laruelle and Peyrouse 2012, 108). "The lands were rented to about 3,000 Chinese colonists for a period of ten years" (108). In 2009, rumors once again circulated about a supposed deal between Chinese and Kazakh authorities for the leasehold of farmland. The announcement caused major protests, after which the agreement was canceled (Demytrie 2010; on the Chinese investment in Kazakhstan in 2004, see Altaiskaia Pravda 2004). Finally, as mentioned in the text, a planned change in the Land Code in April 2016 triggered widespread civic protests, after which the government placed a one-year moratorium on the Land Code.

4. Until February 2016 the district was named "Jaloliddini Rumi," and the recent change in name is not yet widely known.

5. Jing Yin Yin Hai has attracted a third Chinese company, the Xinjiang Tianye Water Saving Irrigation System Co. Ltd. (part of Xinjiang Tianye [Group] Co.), to provide the technology for the farms, particularly drip irrigation. Tianye's activities in Tajikistan are also interesting from another perspective; besides this project, the company is engaged in a project that resulted from an agreement between China's Xinjiang Uygur Autonomous Region Department of Agriculture and Tajikistan's Ministry of Agriculture. The Tianye company has been commissioned to execute this state-initiated development project, which was acquired through public bidding. This is thus a typical project in which multiple Chinese state and private commercial actors are engaged, with (sometimes) distinct objectives.

6. As Yan and Chen (2015) assert, the term "cooperative" has sometimes been used purely to obtain governmental support: "Some are fake because they only exist on paper, while others are created by private enterprises. One common dynamic among actually running cooperatives is that big households use them to dominate access to government subsidies, as well as to control the distribution of economic surplus" (Yan and Chen 2015, 379). 
7. Entering Tajikistan from China over land is only possible via the border post at KulmaKarasu. This was opened in 2004 and has increased in importance as a corridor for China's regional expansion. It is only since 2010 that the border has been open all year round. As of February 2016 direct flights between Dushanbe and Beijing exist.

\section{Acknowledgments}

I am grateful for the support provided by the BICAS consortium, the Catharine van Tussenbroekfonds and the Leiden Asia Centre, to enable the field research and writing of this paper. I like to thank Emily Yeh for initiating this special issue, and the anonymous reviewers for their helpful comments on this paper. I also like to thank my supervisors Oane Visser and Frank Pieke, and the assistance by Qi Tian and Solange Chatelard for their insights and valuable input on earlier versions of this paper. Any remaining errors are solely mine.

\section{Disclosure statement}

No potential conflict of interest was reported by the author.

\section{Funding}

This work was supported by research grants provided by the BRICS Initiative in Critical Agrarian Studies (BICAS), the Catharine van Tussenbroekfonds, and the Leiden Asia Center (LAC).

\section{References}

Alden, Chris, and Daniel Large. 2015. “On Becoming a Norms Maker: Chinese Foreign Policy, Norms Evolution and the Challenges of Security in Africa." The China Quarterly 221: 123-142.

Alimov, Rashid K. 2012. Tadzhikistan - Kitai: na puti drug k drugu [Tajikistan-China:Towards Each Other. Is Equal and Mutually Beneficial Dialogue Possible?]. Moscow: IDV Ran.

Altaiskaia Pravda. 2004. "Kitaitsy reshili osvaivat' zemli v Kazakhstane [Chinese Decided to Develop Land in Kazakhstan]." Altaiskaia Pravda, January 30. Accessed July 7, 2015. http:// www.ap.altairegion.ru/023-04/14.html

Asadov, Shokhboz. 2013. Food Security and the Agricultural Cooperation Agenda in Central Asia with a Focus on Tajikistan. Working Paper No. 16. Dushanbe: University of Central Asia.

Asia Plus. 2014. "China Will Help Make Tajikistan's Agriculture High-Technology." Asia Plus, May 15. http://news.tj/en/news/china-will-help-make-tajikistan-s-agriculture-high-technology.

Bitabarova, Assel. 2016. "Contested Views of Contested Territories: How Tajik Society Views the Tajik-Chinese Border Settlement." Eurasia Border Review 6: 63-81.

Bräutigam, Deborah A., and Xiaoyang Tang. 2009. “China's Engagement in African Agriculture: 'Down to the Countryside"' The China Quarterly 199: 686-706.

Bräutigam, Deborah A., and Haisen Zhang. 2013. "Green Dreams: Myth and Reality in China's Agricultural Investment in Africa." Third World Quarterly 34: 1676-1696.

Breslin, Shaun. 2009. “Understanding China's Regional Rise: Interpretations, Identities and Implications." International Affairs 85: 817-835.

Bureau of Foreign Affairs. 2015. "Zhuanfa xinxi:Tajikesitan mianfangchang yu xunzhao Zhongguo Hezuo Huoban [Forwarding Information: Tajikistan Cotton is Seeking a Chinese Partner]." Bureau of Foreign Affairs, Overseas Chinese Affairs Office, May 11. Accessed June 30. http:// www.btwql.gov.cn/wsfw/963020.shtml 
Burkhanov, Aziz, and Yu-Wen Chen. 2016. "Kazakh Perspective on China, the Chinese, and Chinese Migration." Ethnic and Racial Studies 39: 2129-2148.

Centrasia. 2004. “Kitaiskie migranty prodolzhaiut ugrozhat' Kirgizii (anonimnoe pis'mo v redakciiu) [Chinese Migrants Continue to Threaten Kyrgyzstan (An Anonymous Letter to the Editor)]." CentrAsia, July 26. Accessed July 7, 2015. http://www.centrasia.ru/newsA.php?st=1090786200 China State Farms. 2014. "Huangfanqu nongchang qingli chuangjian wuge shifanqu [Huang Fan's Effort to Create a Five Demonstration Area Farm]." China State Farms, October 20. Accessed July 7, 2015. http://blog.sina.com.cn/s/blog_4de7be930102v4ml.html

Chorshanbiyev, Payrav. 2015. "Chinese Investors Reportedly Lease more than 6,300 HA of Arable Lands in Tajikistan." Asia Plus, January 15. Accessed May 18, 2016. http://news.tj/en/news/ chinese-investors-reportedly-lease-more-6300-ha-arable-lands-tajikistan

Collins, Kathleen. 2006. Clan Politics and Regime Transition in Central Asia. Cambridge: Cambridge University Press.

Cook, Seth, Lu Jixia, Henry Tugendhat, and Dawit Alemu. 2016. “Chinese Migrants in Africa: Facts And Fictions from the Agri-food Sector in Ethiopia and Ghana." World Development 81: 61-70.

Cooley, Alexander. 2012. Great Games, Local Rules. The New Great Power Contest in Central Asia. Oxford: Oxford University Press.

Cotula, Lorenzo, Sonja Vermeulen, Rebeca Leonard, and James Keeley. 2009. Land Grab or Development Opportunity? Agricultural Investment and International Land Deals in Africa. Rome: IIED, FAO, IFAD.

Demytrie, Rayhan. 2010. “Kazakhs Protest against China Farmland Lease." BBC News, January 30. Accessed July 7, 2015. http://news.bbc.co.uk/2/hi/asia-pacific/8489024.stm

Dyatlov, Viktor. 2012. "Chinese Migrants and Anti-Chinese Sentiments in Russian Society." In: Frontier Encounters. Knowledge and Practice at the Russian, Chinese and Mongolian Border, edited by F. Billé, G. Delaplace, and C. Humphrey, 71-87. Cambridge: Open Book Publishers.

Embassy of the People's Republic of China to the Republic of Tajikistan. 2015. "Zhongguo zhu Tajikesitan dashi Fan Xianrong chuxi wohui [Chinese Ambassador to Tajikistan Fan Xianrong Attend My Business]." Embassy of PRC in Tajikistan. May 17. Accessed June 1, 2015. http:// tj.china-embassy.org/chn/xwdt/t1157011.htm

Ergasheva, Zarina. 2014. "Rumi District Administration Gives Back Lands from Chinese Farmers." Asia Plus, July 17. http://www.news.tj/en/news/rumi-district-administration-gives-back-landschinese-farmers.

European Council on Foreign Relations. 2015. One Belt, One Road': China's Great Leap Outward. London: European Council on Foreign Relations (ECFR). http://www.ecfr.eu/page/-/China_ analysis_belt_road.pdf.

Farchy, Jack. 2014. "Tajikistan Looks to China as Russian Remittances Dry Up." Financial Times, October 22. http://www.ft.com/intl/cms/s/0/2c87ee20-58f9-11e4-9546-00144feab7de.htmlslide0.

Farchy, Jack. 2016. “China Seeking to Revive the Silk Road." Financial Times, May 9. http://www. ft.com/content/e99ff7a8-0bd8-11e6-9456-444ab5211a2f.

Farmlandgrab.org. 2011. "Tajikistan Agrees to Allow Chinese Farmers to Till Land." Accessed May 12, 2016. http://www.farmlandgrab.org/post/view/18055

Faromarzi, Fozil. 2012. "Tojikon ba Rusiia Chiniho ba Tojikiston? [Tajiks to Russia, Chinese to Tajikistan?]." Nigoh, January 18, 2.

Ganjinai, Ilhom. 2012."Shuii Chini! Krizisi shavhar hal shud? [A Chinese husband. Is the Husband Crisis Solved?]." Nigoh, October 31, 8.

Gong, Qian, and Philippe Le Billon. 2014."Feeding (On) Geopolitical Anxieties: Asian Appetites, News Media Framing and the 2007-2008 Food Crisis." Geopolitics 19: 291-321.

Goodman, David S. G. 2004. "The Campaign to 'Open up the West': National, Provincial-Level and Local Perspectives." The China Quarterly 178: 317-334. 
Grain. 2008. "Seized! The 2008 Land Grab for Food and Financial Security." Grain Briefing, October 2008. Barcelona: Grain.

Gu, Jing. 2009. “China's Private Enterprises in Africa and the Implications for African Development." The European Journal of Development Research 21: 570-587.

Guangzhou Yuandao Xinxi Youxian Gongsi. 2015. Accessed July 6. www.zhiqiye.com/report/ global/1.html?areaName=亚洲\%20-\%20中亚\&country=塔吉克斯坦

Harvey, David. 2003. The New Imperialism. Oxford: Oxford University Press.

Heathershaw, John. 2009. “Tajikistan's Virtual Politics of Peace." Europe-Asia Studies 61: 1315-1336. Henan TV. 2012. "Shipin: Henan nongmin Han Gentian Tajikesitan dang dizhu [Henan Farmer Han Gensheng Becomes Landlord in Tajikistan]." Henan TV, October 13. http://v.youku.com/v_ show/id_XNDYxNDA0ODI4_rss.html.

Henderson, Jeffrey, Richard P. Appelbaum, and Suet Ying Ho. 2013. "Globalization with Chinese Characteristics: Externalization, Dynamics and Transformations." Development and Change 44: 1221-1253.

Hierman, Brent, and Navruz Nekbakhtshoev. 2014. “Whose Land Is It? Land Reform, Minorities, and the Titular 'Nation' in Kazakhstan, Kyrgyzstan, and Tajikistan." Nationalities Papers: The Journal of Nationalism and Ethnicity 42: 336-354.

Hierman, Brent, and Navruz Nekbakhtshoev. Forthcoming. "Land Reform by Default: Uncovering Patterns of Agricultural Decollectivization in Tajikistan." Unpublished Manuscript.

Hofman, Irna, and Peter Ho. 2012. "China's 'Developmental Outsourcing': A Critical Examination of Chinese Global 'Land Grabs' Discourse." The Journal of Peasant Studies 39: 1-48.

Hofman, Irna, and Oane Visser. Forthcoming. "Window Dressing and Benign Neglect: The State, Donors and Elites in Trajectories of Agrarian Change in Post-Soviet Tajikistan." Unpublished Manuscript.

Jing Yin Yin Hai. n.d. "Gongsi jianjie [Company Profile]." Accessed May 14, 2016. http://www. jyyhseed.cn/site/53/aboutus.aspx?mid=20278

Judah, Ben. 2011."Dragon Meets Bear: Reshaping Central Asia." Prospect, February 3. http://www. prospectmagazine.co.uk/world/russia-china-central-asia-tajikistan.

Kassenova, Nargis. 2009. China as an Emerging Donor in Tajikistan and Kyrgyzstan. Russie. Nei. Visions No. 36. Paris: French Institute of International Relations (IFRI).

Kerr, David. 2010. "Central Asian and Russian Perspectives on China's Strategic Emergence." International Affairs 86: 127-152.

Laruelle, Marlène. 2015. “The US Silk Road: Geopolitical Imaginary or the Repackaging of Strategic Interests?" Eurasian Geography and Economics 56: 360-375.

Laruelle, Marlène, and Sébastien Peyrouse. 2012. The Chinese Question in Central Asia: Domestic Order, Social Change and the Chinese Factor. New York: Columbia University Press.

Lerman, Zvi, and David Sedik. 2009. "Agricultural Development and Household Incomes in Central Asia: A Survey of Tajikistan, 2003-2008." Eurasian Geography and Economics 50: 301-326.

Ministry of Foreign Affairs of the Republic of Tajikistan. 2014. "Investment Climate in Tajikistan." Accessed July 13, 2015. http://mfa.tj/en/investment-climate/investment-climate-in-tajikistan. html

Muhammadiqboli, Emomiddin. 2009. “Khitoizatsiia va Bozori Korvon [Sinification of the Korvon Market]." SSSR, May 9, No 19 (35).

Nasriev, M. 2011. "Chin boiad zamini moro bargardonad! [China Must Return Our Land!]." SSSR, March 17, 2.

Nosirjon, M. 2014. "D. Gulmahmadzoda: Az hamkori bo kishovarzoni Chini qanoatmandem [Gulmuhammadzoda D. 'We Are Satisfied with the Collaborative Work of Chinese Farmers]." Khatlon, July 17, 2.

Olimova, Saodat. 2008. "The Multifaceted Chinese Presence in Tajikistan." China and Eurasia Forum Quarterly 7: 61-77. 
Orazgaliyeva, Malika. 2016. "Nazarbayev Declares Moratorium on Latest Land Code Changes, Creates Ministry of Information and Communications." Nation, May 5. http://astanatimes. com/2016/05/nazarbayev-introduces-moratorium-on-new-provisions-in-land-code/.

Pannier, Bruce. 2011. "Tajikistan Agrees to Allow Chinese Farmers to Till Land." Radio Free Europe, January 28. Accessed July 7, 2015. http://www.rferl.org/content/tajikistan_china/2289623. html

Peyrouse, Sébastien, and Gaël Raballand. 2015. "Central Asia: The New Silk Road Initiative's Questionable Economic Rationality." Eurasian Geography and Economics 56: 405-420.

Putz, Catharine. 2016. “Kazakh Land Code Changes Put on Hold." The Diplomat, May 5. http:// thediplomat.com/2016/05/kazakh-land-code-changes-put-on-hold/.

Reeves, Madeleine. 2014. Border Work. Spatial Lives of the State in Rural Central Asia. Ithaca, NY: Cornell University Press.

Robinson, Sarah, lan Higginbotham, Tanya Guenther, and Andrée Germain. 2008. “Land Reform in Tajikistan: Consequences for Tenure Security, Agricultural Productivity and Land Management Practices." In The Socio-Economic Causes and Consequences of Desertification in Central Asia, edited by R. Behnke, 171-203. Dordrecht, NL: Springer.

Rowe, William C. 2009. "Kitchen Gardens" in Tajikistan: The Economic and Cultural Importance of Small-Scale Private Property in a Post-Soviet Society." Human Ecology 37: 691-703.

Sadovskaya, Elena Y. 2007. “Chinese Migration to Kazakhstan: A Silk Road for Cooperation or a Thorny Road of Prejudice?" China and Eurasia Forum Quarterly 5: 147-170.

Sattori, Anvar. 2013. “China as Tajikistan's 'Lender of Last Resort."' Eurasia Daily Monitor 10(108). The Jamestown Foundation.

Schneider, Mindi. 2016. "Dragon Head Enterprises and the State of Agribusiness in China." Journal of Agrarian Change. doi:10.1111/joac.12151.

Shtaltovna, Anastasiya. 2015. “Knowledge Gaps and Rural Development in Tajikistan: Agricultural Advisory Services as a Panacea?" Journal of Agricultural Education and Extension 22: 25-41.

Spoor, Max. 2012. "Agrarian Reform and Transition: What Can We Learn from 'the East'?" The Journal of Peasant Studies 39: 175-194.

State Council. 2015. Vision and Actions on Jointly Building Silk Road Economic Belt and 21st Century Maritime Silk Road, March 28. Accessed May 14, 2016. http://en.ndrc.gov.cn/ newsrelease/201503/t20150330_669367.html

Summers, Tim. 2016. "China's 'New Silk Roads': Sub-National Regions and Networks of Global Political Economy." Third World Quarterly 37: 1628-1643.

Swaine, Michael D. 2014. "Chinese Views and Commentary on Periphery Diplomacy." China Leadership Monitor 44: 1-43. http://www.hoover.org/research/chinese-views-andcommentary-periphery-diplomacy.

TajStat. 2015a. Nishondihandahoi genderii oid ba fa'oliiati istehsolii khojagihoi dehqoni dar solhoi 2009-2014 [Gender indicators in the Production of Dehqon Farming for 2009-2014]. Dushanbe: Statistical Agency of the Republic of Tajikistan.

TajStat. 2015b. Shumorai aholii Jumhurii Tojikiston to 1 Yanvari soli 2015 [The Population of the Republic of Tajikistan on January 1, 2015]. Dushanbe: Statistical Agency of the Republic of Tajikistan.

TajStat. 2016. Macroeconomic Indicators. Dushanbe: Statistical Agency of the Republic of Tajikistan. Accessed May 10. http://www.stat.tj/en/macroeconomic-indicators/

Toleubayev, Kazbek, Kees Jansen, and Arnold van Huis. 2010. "Knowledge and Agrarian De-collectivisation in Kazakhstan." The Journal of Peasant Studies 37: 353-377.

Tursunzoda, Mehrangez. 2013. “Tajik MFA Calls Statement by SDP Leader'Provocation.' Asia Plus, April 16. http://news.tj/en/news/tajik-mfa-calls-statement-sdp-leader-provocation. 
United States Agency for International Development (USAID). 2014. AgTCA Tajikistan Agricultural Technology Commercialization Assessment. Washington, DC: USAID. http://eatproject.org/ docs/EAT_AgTCA_Tajikistan_Report.pdf.

Van Assche, Kristof. 2016. "Afterword: Expertise and Rural Development after the Soviets." In Agricultural Knowledge and Knowledge Systems in Post-Soviet Societies, edited by A.-K. Hornidge, A. Shtaltovna and C. Schetter, 381-391. Bern: Peter Lang.

Vinson, Mark. 2012. "Tajikistan to Lease 6,000 Hectares of Land to China." Eurasia Daily Monitor 9(30). The Jamestown Foundation.

Visser, Oane, and Max Spoor. 2011. "Land Grabbing in Post-Soviet Eurasia: The World's Largest Agricultural Land Reserves at Stake." The Journal of Peasant Studies 38: 299-323.

Wolford, Wendy, Saturnino M. Borras, Ruth Hall, lan Scoones, and Ben White. 2013. "Governing Global Land Deals: The Role of the State in the Rush for Land." Development and Change 44: 189-210.

World Bank. 2015. A Moderate Slowdown in Economic Growth Coupled with a Sharp Decline in Household Purchasing Power. Tajikistan. Economic Update No. 2, Fall 2015. Washington, DC: World Bank Group.

World Bank. 2016. Tajikistan Partnership Program Snapshot. Washington, DC: World Bank Group. http://pubdocs.worldbank.org/pubdocs/publicdoc/2016/4/971041460525814067/TajikistanSnapshot-s2016-en.pdf.

World Bank. (various years). "World Development Indicators." http://databank.worldbank.org/ data/reports.aspx?source=world-development-indicators.

Xinhua. 2014a. "Zhongyuan nongye chuang silu [Henan in Tajikistan $330 \mathrm{~kg}$ Wheat per mu, Three Times higher than Local]." Xinhuanet, June 12. http://www.ha.xinhuanet.com/hnxw/201406/12/c_1111099152.htm.

Xinhua. 2014b. "Zhongguo nongye qiye jiakuai zouchuqu bufa [Chinese Agricultural Company Speeds up the Steps of 'Going Out']." Xinhuanet, August 20. Accessed May 2, 2016. http:// news.xinhuanet.com/local/2014-08/20/c_1112153068.htm

Yan, Hairong, and Yiyuan Chen. 2015. "Agrarian Capitalization without Capitalism? Capitalist Dynamics from Above and Below in China." Journal of Agrarian Change 15: 366-391.

Yan, Hairong, and Barry Sautman. 2010. "Chinese Farms in Zambia: From Socialist to 'AgroImperialist'Engagement?" African and Asian Studies 9: 307-333.

Yeh, Emily T. 2009. "Greening Western China: A Critical View." Geoforum 40: 884-894.

Yuldoshev, Avaz. 2014. "China Expected to Invest more than $\$ 800 \mathrm{mln}$ in Enhancement of Tajikistan's Agrarian Sector." Asia Plus, November 7. http://news.tj/en/news/china-expectedinvest-more-800-mln-enhancement-tajikistan-s-agrarian-sector.

Zhang, Hui. 2015. "Zhongguo yu Tajikesitannongye jingmao hezuo xianzhuang ji qianjing fenxi [The Present Situation and Prospect Analysis of Agricultural Economic and Trade Cooperation Between China and Tajikistan]." World Agriculture 3: 123-127.

Zhang, Qian F., Carlos Oya, and Jingzhong Ye. 2015. "Bringing Agriculture Back in: The Central Place of Agrarian Change in Rural China Studies." Journal of Agrarian Change 15: 299-313. 